\title{
Increasing Students' Higher-Order Thinking Skills Based On Character And Self-Concept Through Environmental Pollution Practicum
}

\author{
Eliaumra $^{1}$, Muhammad Basir ${ }^{2}$, Samsurizal M. Suleman ${ }^{3}$, I Made Budiarsa ${ }^{4}$ \\ \{elia.umra@gmail.com¹, basircyio@yahoo.com², biosamri@yahoo.com³ \\ budiarsa_imade@yahoo.com ${ }^{4}$ \} \\ Biology Education Study Program, Sintuwu Maroso University, Poso Indonesia ${ }^{1}$, Department of \\ Agrotechnology, Tadulako University, Palu Indonesia ${ }^{2}$, Biology Education Study Program, Tadulako \\ University, Palu Indonesia ${ }^{3,4}$
}

\begin{abstract}
Higher-order thinking skills are a main part of learning assessment process. Enable to apply information they just receive, use and create new knowledge or information. This research explores the efforts in increasing higher-order thinking skills based on students' character and self-concept through Environmental Pollution Practicum. This research was quantitative in nature, with one grup pretest-postest design. Population was students from three study programs of universities in Central Sulawesi, Indonesia, with the sample size of 120 students. Data were taken from higher-order thinking skills test, the students' character, and questionnaire of self-concept, later were analyzed through $\mathrm{N}$-Gain test. The results showed that there were increases of percentage analyse skill (C4) of 54\%, evaluate skill (C5) of 53\%, and create skill (C6) of $34 \%$. Overall, the increased percentage reached $45.5 \%$. It is concluded that Environmental Pollution Practicum can improve the students' higher-order thinking skills based on their character and self-concept.
\end{abstract}

Keywords: Higher-order thinking skills, character, self-concept, practicum, environmental pollution.

\section{Introduction}

Higher order thinking skills are thinking at a higher level more than just memorizing facts or explaining about something. Higher order thinking skills can be considered as a widespread use of the mind to find new challenges and manipulate information for reaching possible answers for in new situations[1]. These skills are in line with the objectives of the 21 st century learning which require students to acquire a lot of skills in terms of developing and exploring knowledge. Progress in almost all aspects of life has provided advantages for humans. In the field of education, the advantages come in form of efforts to develop learning models that can assist students to learn not only by memorizing but also more by thinking deeply and thoroughly [2][3].

Progress in all aspects of life also gives global impact on the field of education, for instance, requiring universities to produce graduates that are skilled professionally in their respective field, with broad personality traits of both the $21^{\text {st }}$ century skills and competences, or generally called as the $21^{\text {st }}$ century skills [4][5][6][7]. In several references of education, this phrase "the $21^{\text {st }}$ century skills" refers to "readiness of college and career", "next generation learning", and 
"deep learning". The skills required in the $21^{\text {st }}$ century learning are communication skills, collaboration skills, professionalism skills, and higher order thinking skills which consist of critical thinking, skills to adapt, and interpersonal skills. All those skills are a must for students who want to integrate themselves and develop in today's job market [5][8].

Interpersonal skills depend on an individual's character. A person's character reflects are values and norms that that person has, including reasons underlying his or her every behaviors. One of the factors that contribute to someone's character is environment. Furthermore, a person's character has three operative values. First, is value in action, or three demonstrative behaviors that are interrelated to teach other, namely moral of knowing (cognitive aspect), moral of feeling (affective aspect), and moral of behavior (psychomotor aspect). A person with good character will show the following processes: knowing which one is good, desiring to do what is good, and doing what is good [9].

Hoge defines character education as a way to adjust students' behaviors to become wellbehaved citizens. Pike adds that students are instructed and guided to have a set of behaviors which are determined as values as taught in character education. In addition to that, Marshall, et al claim that character education is continually trusted since this field enables the educators to view students in various ways through different perspectives, such as well-behaved and wellmannered students, and to practice their maturity in challenging situations[10][11][12].

Improving character-based higher order thinking skills is possible to be done by integrating character avalues in the assessment system and learning curriculum, such as by integrating character education in learning materials. That means that character education is not separated from the learning curriculum. In relation to this, a strategy often implemented by developed countries is requiring all educators, education staff, counselors, and administration staff to become good examples for students. The strategy related to the existence of a character model that is often carried out in developed countries is that all teaching staff and education staff, all guidance and counseling staff, and all administrative staff must be able to become good models [9].

A number of studies have proven that the implementation of character education in schools had positive impacts to students who previously had bad behaviors; for instance, improving their academic achievement and reducing the number of school dropouts. Overall, character education expects that students' development must be one important component embedded in the current curriculum [13]. This research emphasizes the characteristics of attentiveness, analyticity, commitment, initiative, problem solving, innovative, curiosity, skillfulness, integrity, responsibility, neatness, mutual cooperation, accuracy, honesty, discipline, agility, work ethic, self-confidence and self-sacrifice.

Besides character, a person's self-concept can also show his or her interpersonal skills, since self-concept is a combination of that person's physical, personal, moral, family, social and academic domains [14][15]. A person's self-concept is also known by several other terms, namely self-construction, self-identity, and self-perspective. Self-concept can be defined as a someone collection of beliefs about oneself that includes various elements such as academic achievement, gender roles and sexuality, and racial identities. In general, self-concept embodies the answer to "who am I" question, a lifetime question. Someone's self-concept consists of their past, present, and future self scheme. The concept of one's self consists of their self-schema of the past, the present and the future. This concept is different from self-awareness, which refers to the extent to which self-knowledge is defined, consistent, and currently applies to a person's attitude and disposition. Meanwhile, self-concept itself can be defined as "an individual's beliefs about him or herself, including that person's attributes of who and what that person is" 
[16]. Higher-order thinking skills are strongly influenced by self-concept, based on the assumption that someone with a good self-concept will have good thinking skills too.

Higher-order thinking skills are very important to develop. These skills enable students to apply information they receive, to see the relationship between what is supposed to be taught with their prior knowledge, to use knowledge or information they have in order to create new knowledge and information, to understand difficulties and challenges they face, and to analyze and make wise decision as well. Higher-order thinking skills become a main part in learning assessment [17][18].

Bloom's Taxonomy is the foundation for higher-level thinking skills, based on the notions that certain types of learning require cognition process more than the other types yet with more general advantages. Bloom's Revised Taxonomy shows that thinking skills involve analyze skills (C4), evaluate skills (C5) and create skills (C6) which are regarded as higher level set of thinking skills[19]. Furthermore Krathworl state that the indicators to measure higher-level thinking skills include the followings [20]:

a. Analyze

(1) Analyzing incoming information and breaking it down, or structuring information into smaller parts to recognize patterns or relationships of information with others information, (2) able to recognize and distinguish causal factors and effects of a complicated scenario, (3) Identifying or formulation questions.

b. Evaluate

(1) Evaluating a solution, idea, and method with suitable criteria or existing standards in order to ensure its effectiveness values or advantages, (2) making hypothesis, criticizing, or testing, (3) accepting or receiving a statement based on set criteria.

c. Create

(1) Generating an idea or point of view on something, (2) designing solution to a problem, (3) organizing elements to become a new structure.

The higher-order thinking skills listed previously can be improved through practical activities or practicum, because practicum cannot be separated from steps in scientific methods that enable students to practice their skills to experiment, discover, and deduce their experimental results. Practicum provides opportunities for students to practice improving their skills in order to implement knowledge they have learned previously. Practicum can also make students able to understand concepts in depth and understand science as both processes and products. Therefore, practicum has significant roles in developing higher-order thinking skills and scientific process.

The results of research done by Ikonomopoulos et. al report that practicum activities have increased graduate students' self-efficacy.In consistent with their research, Kang also shows that practicum can increase prospective teacher students' social identity and academic professionalism. However, Ibrahim's research shows different results, since his research shows that there is no increase in preservice secondary school teachers' academic achievement after conducting assisted by the use of technology and information [21][22][23].

This article discusses about the improvement of higher-order thinking skills based on university students' self-concept and character through environmental pollution practicum. 


\section{Method}

The research method used in this research was pre-experimental design with one grup pretest-postest design with the following formula [24].

$\mathrm{O} 1 \quad \mathrm{X} \quad \mathrm{O} 2$

$\mathrm{X}=$ treatment of the experimental group

$\mathrm{O} 1=$ Pre-test

$\mathrm{O} 2=$ Post-test

The research location took place in three study programs or departments in Central Sulawesi Province: Biology Education Study Program of Tadulako University Palu, Biology Education Study Program of Sintuwu Maroso University Poso, and Environmental Health Study Program of Ministry of Health Polytechnic Palu. Population in this research was students of those three study programs who have enrolled in the course of Environmental Pollution in even semester of academic year 2018/2019. The sample taken using total sampling method was 120 students.

Data on higher-order thinking skills were obtained through essay test consisted of 9 question items distributed to test the students' analyse skill, evaluate skill, and create skill. The test was given before and after conducting practicum on three experiments, which were water pollution, air pollution, and soil pollution. The range of score given was $0-100$. The $\mathrm{N}$-gain test was conducted to analyze the increase on students' higher-order thinking skills with the following equation[25]:

$$
N \text {-gain }=\frac{\text { score of post test }- \text { pre test }}{\text { Ideal maximum score }- \text { pre test score }} \times 100 \%
$$

Categories of $\mathrm{N}$-gain were determined through analyzing the results of pre-test and posttest using the criteria proposed by Hake [25] as presented in Table 1

Table 1. N-gain categories.

\begin{tabular}{ll}
\hline $\mathrm{N}$-gain & Categories \\
\hline $\mathrm{g}>0,7$ & Higih \\
$0,3<\mathrm{g}<0,7$ & Medium \\
$\mathrm{g}<0,3$ & Low \\
\hline
\end{tabular}

Data of the students' character were obtained from observations while participating in Environmental Pollution Practicum activities. The character values assessed were attention, analytical, commitment, initiative, problem solving, innovative, curiosity, skillfulness, integrity, responsibility, neatness, mutual cooperation, accuracy, honesty, discipline, agility, work ethic, self-confidence, and self-sacrifice. The score was given using a Likert scale of 15. Criteria for the students' character were based on modifying Riduwan's criteria [26] which are presented in Table 2.

Table 2. Character categories.

\begin{tabular}{ll}
\hline Interval of score & Categories \\
\hline $81-100 \%$ & Very Good \\
$61-80 \%$ & Good \\
$41-60 \%$ & Average
\end{tabular}




\begin{tabular}{ll}
$21-40 \%$ & Bad \\
$0-20 \%$ & Very Bad \\
\hline
\end{tabular}

Data of the students' self-concept were obtained from distributing questionnaires consisted of 20 items, which were statements on students' academic ability in favorable and unfavorable questions. The score was given using a Likert scale of 1-5. The students' selfconcept was determined by calculating the highest and lowest score as presented in Table 3 .

Table 3. Shelf-concpet categories.

\begin{tabular}{ll}
\hline Interval of score & Categories \\
\hline $85-100$ & Very high \\
$69-84$ & High \\
$53-68$ & Medium \\
$37-52$ & Low \\
$20-36$ & Very low \\
\hline
\end{tabular}

\section{Research Result and Discussion}

\subsection{Improving Increased Higher-Order Thinking Skills Through Environmental Pollution Practicum}

Table 4 displays the data on analysis skill (C4) that were taken before and after the Environmental Pollution Practicum was conducted.

Table 4. Increase on analysis skill (C4) through environmental pollution practicum.

\begin{tabular}{lcllll}
\hline University & Pre test & Post test & N-gain & $\%$ & $\begin{array}{l}\text { Category } \\
\text { of increase }\end{array}$ \\
\hline $\begin{array}{l}\text { Ministry of Health } \\
\text { Polytechnic of Palu }\end{array}$ & 59 & 82 & 0,55 & 55 & Medium \\
Tadulako University & 37 & 76 & 0,62 & 62 & Medium \\
$\begin{array}{l}\text { Sintuwu Maroso } \\
\text { University }\end{array}$ & 50 & 73 & 0,46 & 46 & Medium \\
\hline
\end{tabular}

As seen in Table 4, there was an increase of percentage for analysis skill (C4), which was around $46 \%-55 \%$ and categorized as medium. This increase means that practicum could increase the students' skills to think, deeply stimulated their curiousity about what they were learning at that time, and gave them new experiences as well. Through Environmental Pollution Practicum, the students could witness the impacts of environmental pollution on living creatures, thus giving them the sensation of real life learning. They felt that they had been challenged with new challenge and tried to look for information that was related to the practicum topic, as shown in Figure 1. 


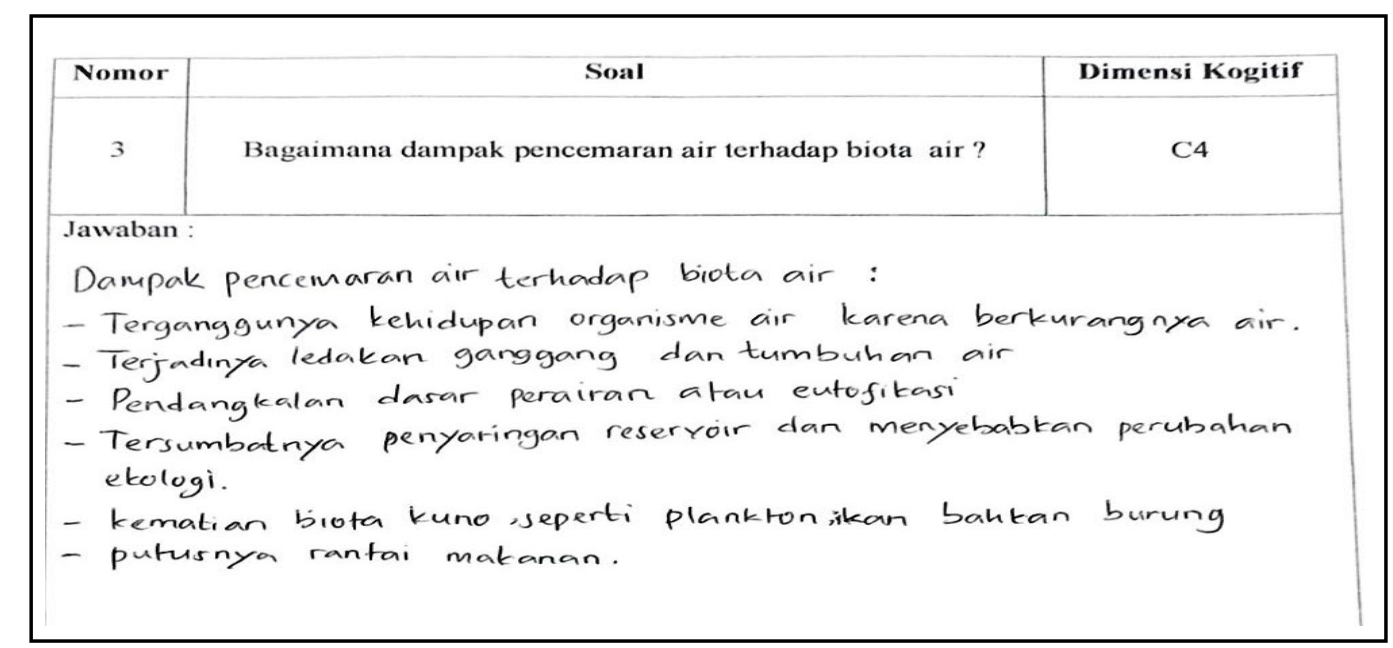

Fig. 1. Higher-order thinking skills of C4 cognitive level.

Figure 1 shows that the students were able to analyze the impacts of water pollution on biota, combined their prior knowledge with information they were studying at the same time, and described a real life situation based on its context. These results prove that the learning objectives expected were achieved through practicum. Also, this is consistent with Krathwohl's statement about analysis skill as an ability to break down certain materials into clearer components. This ability can take form in analyzing elements (analyzing parts of materials), analyzing relationships (identification of relationships), and analyzing the organization of principles (organizational identification)[20].

Next, Table 5 displays the data on evaluation skill (C5) that were taken before and after the Environmental Pollution Practicum was conducted.

Table 5. Increase on evaluation skill (C5) through environmental pollution practicum.

\begin{tabular}{llllll}
\hline University & Pre test & Post test & N-gain & $\%$ & $\begin{array}{l}\text { Category } \\
\text { of increase }\end{array}$ \\
\hline Ministry of Health & 26 & 68 & 0,55 & 55 & Medium \\
Polytechnic of Palu & & & & & \\
Tadulako University & 29 & 71 & 0,59 & 59 & Medium \\
$\begin{array}{l}\text { Sintuwu Maroso } \\
\text { University }\end{array}$ & 38 & 67 & 0,46 & 46 & Medium \\
\hline
\end{tabular}

Table 5 shows that there was an increase of percentage for evaluation skill (C5) ranged from $46 \%-59 \%$ and categorized as medium. This means that students showed good evaluation skill. This evaluation ability is based on one example of students' test answer given to them after practicum, as seen in Figure 2. 


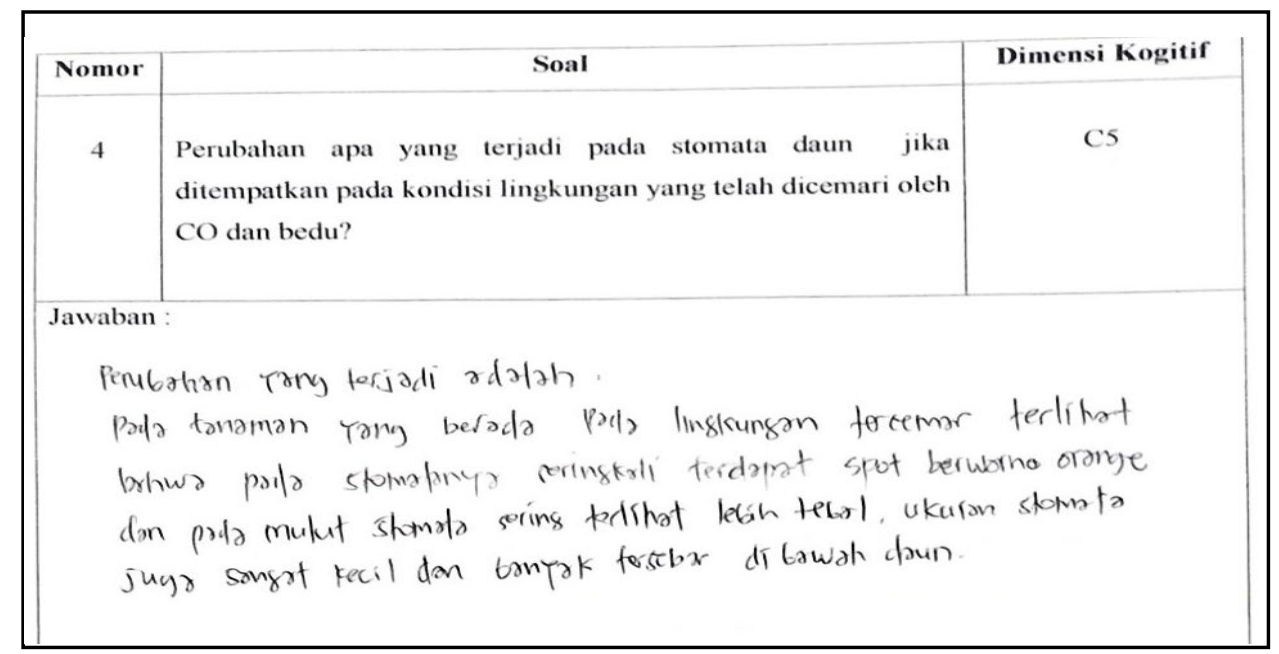

Fig. 2. Higher-order thinking skills of C5 cognitive level.

Higher-level thinking skills on the C5 cognitive dimension (Evaluation skill) in Figure 2 shows that the students were able to make an evaluation of certain situation, and make decisions based on what they had learned through practicum. Also, Figure 2 proves that practicum activities were able to improve the students' thinking skills and understanding of subject matter, since practicum is a series of scientific activities including formulating problems, designing experiments, assembling tools, conducting experiments, observing and interpreting data obtained. Practicum therefore, can make the students discover knowledge through exploration of their natural surroundings.

Furthermore, the improvement of creation skill (C6) taken before and after the Environmental Pollution Practicum was conducted is shown by Table 6.

Table 6. Increase on create skill (C6) through environmental pollution practicum.

\begin{tabular}{llllll}
\hline University & Pre test & Post test & N-gain & $\%$ & $\begin{array}{l}\text { Category } \\
\text { of increase }\end{array}$ \\
\hline $\begin{array}{l}\text { Ministry of Health } \\
\text { Polytechnic of Palu }\end{array}$ & 42 & 59 & 0,28 & 28 & Low \\
Tadulako University & 31 & 60 & 0,42 & 42 & Medium \\
$\begin{array}{l}\text { Sintuwu Maroso } \\
\text { University }\end{array}$ & 34 & 56 & 0,33 & 33 & Medium \\
\hline
\end{tabular}

As seen in Table 6, the increase of percentage for create skill (C6) was ranged around $28 \%$ to $42 \%$ and categorized as low and medium increase. These findings show that the students were not fully able to create something new based on their experiences while participating in practicum activities. The skill to create is related to creative thinking process; however, this skill does not totally affect the students' ability to create something new. This is also proven by the students' test answer on the C6 cognitive dimension given after the practicum, as seen in Figure 3. 


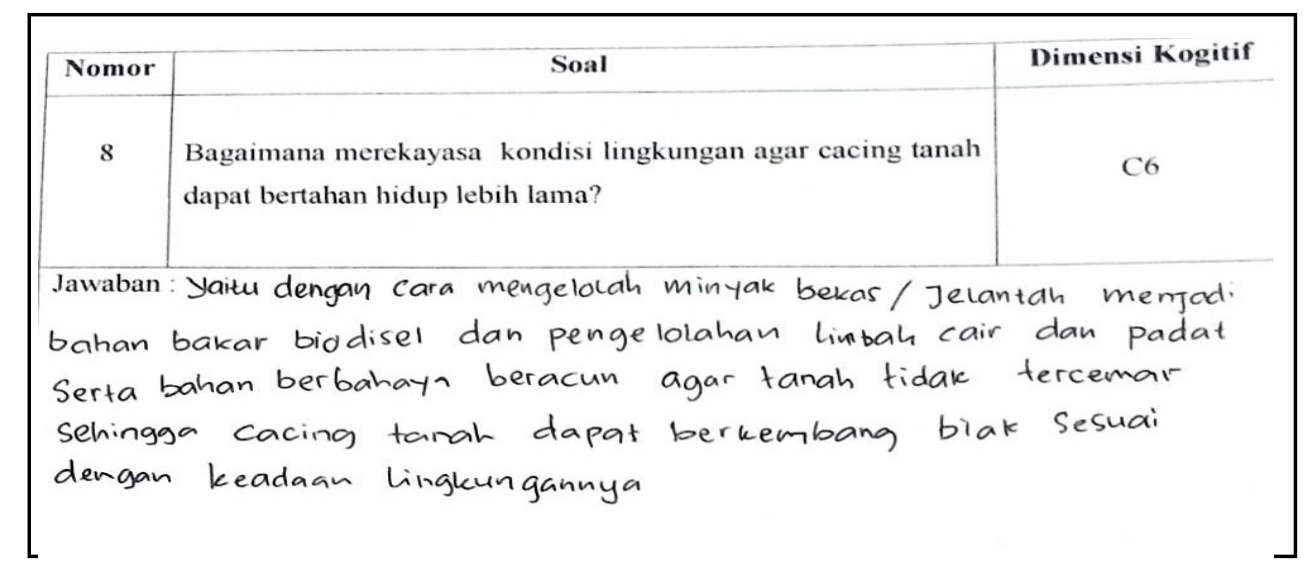

Fig. 3. Higher-order thinking skills of C6 cognitive level.

Figure 3 shows that the students' ability to create something new was still limited to what they had received during practicum. Create skill is indicated by the ability to create new product by organizing several elements into new forms or patterns that are different from before. This is consistent with Krathwohl's [20] explanation about create skill, which is the ability to generate and produce. Generating is an activity that represents problems and finds alternative to required hypotheses. Furthermore, generating is related to divergent thinking as the core of creative thinking. Meanwhile, producing leads to planning to solve a given or faced problem. Producing is closely related to other dimensions of knowledge, namely factual knowledge, conceptual knowledge, procedural knowledge, and metacognitive knowledge.

Overall, the increase of higher-order thinking skills through Environmental Pollution Practicum is shown in Figure 4.

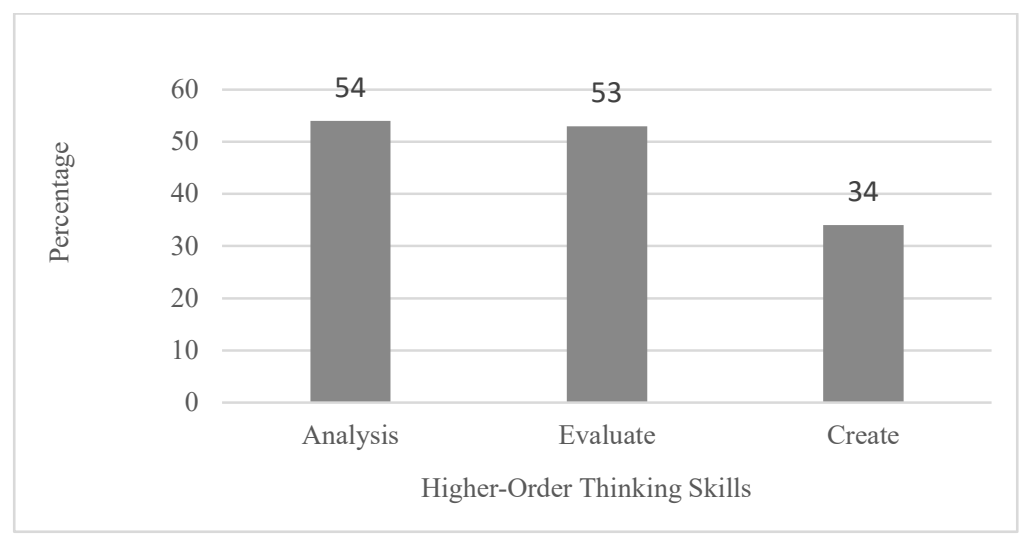

Fig. 4. Percentage of Increase on Higher-Order Thinking Skills through Environmental Pollution Practicum.

Figure 4 shows a visible increase on three cognitive dimensions which are analysis skill, evaluation skill, and create skill. The increased percentage was around $34 \%-54 \%$, which 
shows that the students have understood the concepts, been able to apply information they received, and been able to create information and knowledge. Practicum activities have been proven to provide extensive experience for the students to improve their cognitive, affective, and psychomotor skills. Improving cognitive skills means that the students can train themselves to understand the theories taught to them, can integrate different theories, and apply those theories to real situations. Next, improving affective skills means that the students can plan their learning activities independently, collaborate, appreciate and communicate information related to their fields of knowledge. Later, improving psychomotor skills means that the students are able to prepare tools, install and use certain instruments, thus practicing their thinking skills to master the use of those tools and instruments.

\subsection{The Students' Character and Self-Concept during Environmental Pollution Practicum}

The results of the students' character analysis shown during Environmental Pollution Practicum are displayed in Table 7.

Table 7. The students`s shown character during environmental pollution practicum.

\begin{tabular}{lll}
\hline University & Score of Character (\%) & Category of Increase \\
\hline Ministry of Health & 80,5 & High \\
$\begin{array}{l}\text { Polytechnic of Palu } \\
\text { Tadulako University }\end{array}$ & 82 & \\
$\begin{array}{l}\text { Sintuwu Maroso } \\
\text { University }\end{array}$ & 79,9 & Very high \\
\hline
\end{tabular}

Table 7 shows that the characters shown by students during the Environmental Pollution Practicum were well-behaved and well-mannered. The scores prove that the students have been through a learning process to understand, accept and act based on the values of virtue and responsibility towards themselves and others. This is also in accordance with the definition of character education by the Ministry of National Education who states that character education is a system of instilling character values in the communities of school, which includes components of knowledge, awareness or willingness, and actions to perform these values towards God the Almighty, one-self, others, environment, and the nation in order to become a wholeness human being [27].

The results of the students' self-concept during Environmental Pollution Practicum are displayed in Table 8.

Table 8. The students' shelf-concept during environmental pollution practicum.

\begin{tabular}{lll}
\hline University & Score of shelf-concept (\%) & Category of Increase \\
\hline $\begin{array}{l}\text { Ministry of Health } \\
\text { Polytechnic of Palu }\end{array}$ & 76,43 & High \\
Tadulako University & 78 & High \\
Sintuwu Maroso & 80 & High \\
University & & \\
\hline
\end{tabular}


Table 8 shows that the students' self-concepts as the results of this research were categorized as high, proving that the students already possessed high confidence in their academic abilities. Their high confidence was shown by their ability to answer the questions given, thus it can also be said that most of the students already had good self-concept of their academic abilities. Also, they already had good cognitive development compared to secondary level students. University students already have deep understanding on what they experience or how they will react to the stimulants they get from their surrounding environment, where one of the stimulants is practicum activities. This is also in line with Yosup et al's definition about self concept [15].

\subsection{Improving Higher Order Thinking Skills Based on Character and Self-Concept The Students' Character and Self-Concept during Environmental Pollution Practicum}

The results of the students' increase on their character-based higher-order thinking skills during Environmental Pollution Practicum are displayed in Table 9.

Table 9. Increase on character-based higher order thinking skills through environmental pollution practicum .

\begin{tabular}{|c|c|c|c|}
\hline Character & $\begin{array}{l}\text { Number } \\
\text { students }\end{array}$ & of N-gain & $\begin{array}{l}\text { Increase } \\
\text { percentage }(\%)\end{array}$ \\
\hline Very good & 64 & 0,48 & 48 \\
\hline Good & 56 & 0,42 & 42 \\
\hline Pretty good & 0 & 0 & 0 \\
\hline Not good & 0 & 0 & 0 \\
\hline $\mathrm{Bad}$ & 0 & 0 & 0 \\
\hline
\end{tabular}

Table 9 shows that the increases on higher-level thinking skills before and after the Environmental Pollution Practicum were almost the same, which was $48 \%$ in the category of Very Good Character with 64 students and 42\% in the category of Good Character with 56 students. These results are in line with Jeynes' research result which proves that character education has an influence on higher education students' learning achievement, while their character does not give different effect on each student. Another supporting research result is from Zubaidi who states that character is an integration of intelligence, personality and nobleness. Character can build someone's habits to always give his or her best as an achievement instilled with noble values. Furthermore, Lickona also adds that good character is supported by knowledge of goodness, desire to do what is good, and doing good deeds [28][29][30].

The results of the students' increase on their higher-order thinking skills based on selfconcept during Environmental Pollution Practicum are displayed in Table 10.

Table 10. Increase on higher order thinking skills based on self-concept through environmental pollution practicum .

\begin{tabular}{|c|c|c|c|}
\hline Character & $\begin{array}{l}\text { Number } \\
\text { students }\end{array}$ & of $\mathrm{N}$-gain & $\begin{array}{l}\text { Increase } \\
\text { percentage }(\%)\end{array}$ \\
\hline Very high & 22 & 0,54 & 54 \\
\hline High & 84 & 0,44 & 44 \\
\hline
\end{tabular}




\begin{tabular}{llll} 
Medium & 14 & 0,41 & 41 \\
Low & 0 & 0 & 0 \\
Very low & 0 & 0 & 0 \\
\hline
\end{tabular}

Table 10 shows that the highest increase in higher-order thinking skills based on selfconcept was in the category of Very High with 22 students (54\%), while in the category of High was 85 students (44\%). Furthermore, there were 13 students in the category of Medium $(41 \%)$, and no increase in the categories of Low and Very Low. From these increased percentages, it can be said that the students with very high self-concept also had a good level of self-confidence, resulting good academic abilities. These results are in line with Dagnew' research which proves that self-concept has a significant relationship with academic ability. Also, the students' performance are influenced by various factors, among others, are self-concept and motivation, due to a new paradigm of learning which assumes that all students can and should learn at higher level. The results are also supporting the research from Chao et al who also find that self-concept and efficacy are the most significant factors in student learning achievement [31][32].

The results of the increased percentages on character and self-concept based higher-order thinking skills through Environmental Pollution Practicum are displayed in Figure 5.

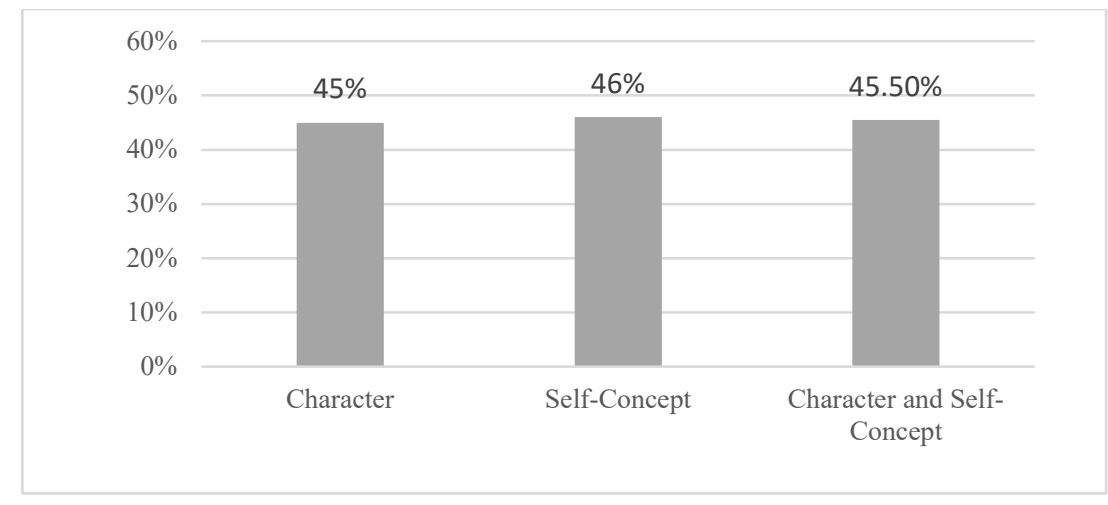

Fig. 5. Percentage of Increase on character and self-concpet based Higher-Order Thinking Skills through Environmental Pollution Practicum.

Figure 5 shows that the highest increase of higher-order thinking skills through Environmental Pollution Practicum was in self-concept variable, which reached $46 \%$. This means that self-concept has a significant role on the students' higher-order thinking skills. According to Dagnew, self-concept must be built from early age and continues to grow over time. Burn et al also explains that self-concept consists of two main factors, namely selfperception of someone's competence and its impact on education outcomes. Increased highlevel thinking skills based on characters acquired percentage of $45 \%$, which means that the character can influence the thinking skills of students, because the characters are able to form and develop the potential of students to think good, be good and well behaved. Furthermore, the increase of character-based higher-order thinking skills reached $45 \%$. It means that character can influence students' thinking skills, since character is able to build and develop their competences to think good, kind and sincere, and well-behaved. 
Overall, the increased percentage of higher-order thinking skills based on character and self-concept reached $45.5 \%$, categorized as Medium. Thus, it is proven that both character and self-concept have significant roles in improving the students' higher-order thinking skills through Environmental Pollution Practicum.

\section{Conclusion}

This research shows that through Environmental Pollution Practicum, there is an increased percentage of higher-order thinking skills on $\mathrm{C} 4$ cognitive dimension (analyse) of $54 \%, \mathrm{C} 5$ (evaluate) of $53 \%$, and C6 (create) of 34\%. Furthermore, the average number of increased percentage on character and self-concept based higher-order thinking skills is $45.5 \%$.

For future research, it is suggested to continue practicum activities in regard to improving students' create skill, as well as to conduct further research on factors that influence students' lack of product creation skill in practicum activities.

\section{Acknowledgment}

The authors would like to thank rector of Sintuwu Maroso University for support financial this study. We also to thank the head of the Biology Department of Tadulako University and the Department of Environmental Health, Ministry of Health, Palu.

\section{References}

[1] M. . Heong, Y. M., Othman, W.D., Md Yunos, J., Kiong, T.T., Hassan, R., and Mohamad, "The Level of Marzano Higher Order Thinking Skills Among Technical Education Students," Int. J. Soc. Humanit., vol. 1, no. 2, pp. 121-125, 2011.

[2] A. Gullamhussesin, Teaching the Teachers, Effective Professional Development in an Era of High Stakes Accountability. Center for Public Education, 2013.

[3] P. J. Nesbitt-Hawes, "Higher Order Thinking Skills In Science Classroom Computer Simulation. Queensland University of Technology," Queensland University of Technology, Brisbane, 2005. [Online]. Available: https://eprints.qut.edu.au/16201/1/Philip_Nesbitt-Hawes_Thesis.pdf.

[4] M. Binkley, M., Erstad, O., Herman, J., Raizen, S., Ripley, M., Miller-Ricci, M., \& Rumble, Defining twenty-first century skills. In Assessment and teaching of 21 st century skills. Netherlands: Springer, 2012.

[5] L. Casner-Lotto, J., \& Barrington, "Are They Really Ready to Work? Employers' Perspectives on the Basic Knowledge and Applied Skills of New Entrants to the 21st Century US Workforce," Consortium of The Conference Board, Corporate Voices for Working Families, the Partnership for 21st Century Skills, and the Society for Human Resource Management, 2006. [Online]. Available: https://files.eric.ed.gov/fulltext/ED519465.pdf.

[6] J. J. Duderstadt, Engineering for a changing world: A roadmap to the future of American engineering practice, research, and education. In D. Grasso and M. B. Burkins (Eds), Holistic Engineering Education: Beyond Technology. New York: Springer, 2010.

[7] V. Greenhill, "21st Century Knowledge and Skills in Educator Preparation," Collaborative 
project by the American Association of Colleges of Teacher Education and the Partnership for 21st $\begin{array}{lllll}\text { Century Skills, 2010. } & \text { [Online]. } & \text { Available: }\end{array}$ http://www.p21.org/storage/documents/aacte_p21_whitepaper2010.pdf.

[8] M. L. Pellegrino, J. W., \& Hilton, Education for Life and Work: Developing Transferable Knowledge and Skills in the 21st Century. Washington DC: National Academies Press, 2012.

[9] M. Samani and Hariyanto, Pendidikan Karakter. Konsep dan Model. Bandung: Remaja Rosdakarya, 2016.

[10] J. Hoge, "Character education, citizenship education, and the social studies," J. Soc. Stud., vol. 93, no. 3, pp. 103-109, 2002.

[11] M. A. Pike, "Christianity and character education: faith in core values," J. Beliefs Values Stud. Relig. Educ., vol. 31, no. 3, pp. 311-312, 2010.

[12] J. Marshall, Jon C., Caldwell, Sarah D., and Foster, "Moral Education the Character 'plus' Way[R]," J. Moral Educ., vol. 40, no. 1, pp. 51-72, 2011.

[13] M. Berkowitz, M. W., and Hoppe, "Character education and gifted children," High Abil. Stud., vol. 20, no. 2, pp. 131-142, 2009.

[14] W. L. Fitts, W. H., and Warren, Tennessee self-concept scale: Manual, 2nd ed. Los Angeles, CA: Western Psychological Services, 2003.

[15] F. Yusop,Y. M, Sumari, M, and Mohamed, "The Needs Analysis in Self-Concept Module Development,” Malaysian Online J. Educ. Sci., vol. 3, no. 1, pp. 44-55, 2015.

[16] P. A. Lone, "A Study on Relation between Self Concept and Academic Achievement among Secondary School Students of Jammu District,” J. Educ. Pract., vol. 7, no. 31, pp. 19-23, 2016.

[17] Y. Rustaman, Nuryani, "Pendidikan dan Penelitian Sains dalam Mengembangkan Keterampilan Berpikir Tingkat Tinggi Untuk Pembangunan Karakter," Pros. Semin. Nas. Biol., vol. 8, no. 1, pp. 15-34, 2011.

[18] D. Husamah, Fatmawati, D., \& Setyawan, "OIDDE Learning Model: Improving Higher Order Thinking Skills of Biology Teacher Candidates," Int. J. Instr., vol. 12, no. 11, pp. 249-264, 2018.

[19] L. . Krathwohl, D.R. and Anderson, . A Taxonomy For Learning, Teaching, And Assesing; A Revision Of Bloom's Taxonomy Of Education Objective. New York: David MacKay Company, Inc, 2001.

[20] D. R. Krathwohl, “A revision of Bloom's Taxonomy: an overview - Theory Into Practice, College Of Education, The Ohio State University Pohl. Learning to Think, Thinking To Learn," 2002.

[21] J. Ikonomopoulos, James; Vela, Javier Cavazos; Smith, Wayne D.; Dell'Aquila, "Examining the Practicum Experience to Increase Counseling Students' Self-Efficacy," Prof. Couns., vol. 6, no. 2, pp. 161-173, 2016.

[22] J. Kang, "International Pre-Service Teachers' Practicum Experiences in the U.S.: Ethnographic Case Studies," Michigan State University, 2017.

[23] H. G. Ibrahim, "Utilization of Innovations and Techniques of Educational Technology in Delivering of Educational Practicum and Its Impact on Increasing Academic Achievement among Pre-Service Teachers," J. Educ. Pract., vol. 8, no. 8, pp. 185-195, 2017.

[24] Sugiyono, Metode Penelitian Pendidikan Pendekatan Keuantitatif, Kualitatif, dan R\&D. Bandung: Alfabeta, 2017. 
[25] R. R. Hake, “Analyzing Change/Gain Scores,” www.physics.indiana. edu, 1999. .

[26] Riduwan, Belajar Mudah Penelitian Guru, Karyawan dan Peneliti Pemula, Alfabeta. Bandung, 2009.

[27] Kementerian Pendidikan Nasional, "Sambutan Menteri Pendidikan Nasional Pada Peringatan Hari Pendidikan Nasional, Senin 2 Mei 2011,” www.kemdiknas.go.id,2011. .

[28] W. H. Jeynes, "A Meta-Analysis on the Relationship between Character Education and Student Achievement and Behavioral Outcomes," Educ. Urban Soc., vol. 51, no. 1, pp. 33-71, 2019.

[29] Zubaedi, Desain Pendidikan Karakter, Konsepsi dan Aplikasinya dalam Lembaga Pendidikan. Jakarta: Kencana Prenada Media, 2013.

[30] T. Lickona, Educating for Character: Mendidik untuk membentuk karakter. Terjemahan. Jakarta: Bumi Aksara, 2012.

[31] A. Dagnew, "The Relationship among Parenting Styles, Academic Self-Concept, Academic Motivation and Students' Academic Achievement in Fasilo Secondary School, Bahir Dar, Ethiopia," Res. Pedagog., vol. 8, no. 2, pp. 98-110, 2018.

[32] B. Chao, Chih Nuo Grace; McInerney, Dennis M.; Bai, "No Title," Asia-Pacific Educ. Res., vol. 28, no. 2, pp. 139-147, 2019.

[33] R. B. Burns, Richard A.; Crisp, Dimity A.; Burns, "Competence and Affect Dimensions of Self-Concept among Higher Education Students: A Factorial Validation Study of an Academic Subject-Specific Self-Concept," Eur. J. Psychol. Educ., vol. 33, no. 4, pp. 649-663, 2018. 